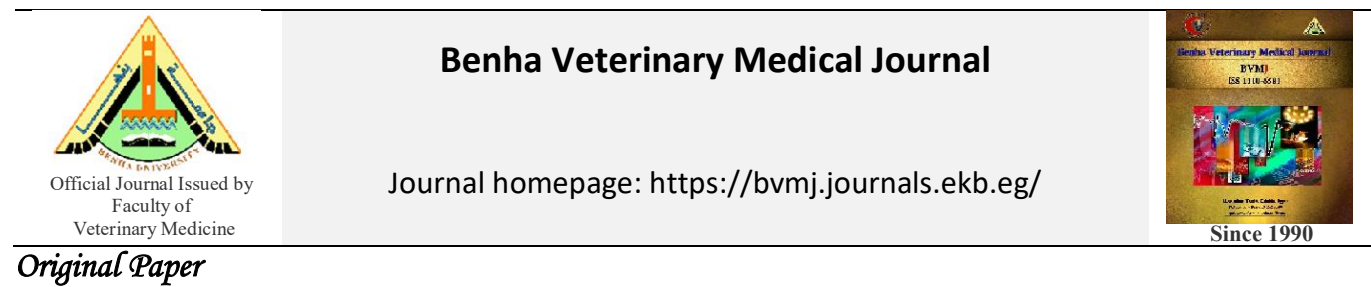

\title{
Bacteriological studies on methicillin -resistance Staphylococcus aureus (MRSA) isolated from cow's mastitis milk.
}

Alaa N. Anter, Ashraf A. Abd El Tawab, Fatma I. El-Hofy

Department of Bacteriology, Immunology and Mycology, Faculty of Veterinary Medicine, Benha University, Egypt

\begin{tabular}{l} 
ARTICLE INFO \\
\hline Keywords \\
PCR \\
mecA gene \\
Methicillin -resistant \\
staphylococcus aureus \\
(MRSA
\end{tabular}

Received 18/03/2021

Accepted 23/03/2021

Available On-Line

$01 / 07 / 2021$

\begin{abstract}
An enormous problem reported worldwide namely bovine mastitis caused by MDR (multidrug resistant) $S$. aureus results in prolonged antibiotic treatment and livestock death. Mastitis caused by pathogenic $S$. aureus strains led to a focused study on surveillance of antibiotic susceptibility along with phenotypic and genotypic characterization. The isolation of Staphylococcus aureus to the determination of antibiotic susceptibility pattern from obtained cow's milk samples was the aim of the current study. Cows affected by mastitis from different farms in Kalyuobia Governorate, one hundred milk samples were conducted for $S$. aureus isolation with a prevalence of $30 \%$ where $20 \%$ isolates were coagulase positive (CoPS) and $10 \%$ isolates were coagulase negative CoNS (Gram staining, oxidase, catalase, DNase, hemolysis, and the coagulase test were employed for bacterial identification). The majority of the strains (COPS) $n=20$ was profiled revealing antimicrobial sensitivity to be multidrug resistant. The occurrence of oxacillin susceptible mecA strains positive strains (OS-MRSA) was revealed in 6 strains for the first time. Identification of MRSA strain by detection of mecA gene in the PCR.
\end{abstract}

\section{INTRODUCTION}

Staphylococcus aureus is a pathogenic gram-positive, facultative anaerobe bacterium that represents worldwide threat to man and animals (Nemeghaire et al., 2014). staphylococcus aureus infections in cattle can result in several disease conditions including, mastitis, skin and GIT infections, osteomyelitis, meningitis, pneumonia, endocarditis and toxic shock syndrome (Pal et al., 2020). Staphylococcus aureus -induced mastitis represents a significant infectious disease resulting in severe economic losses to the dairy industry worldwide; moreover, economic losses resulting from Staphylococcal mastitis were estimated at around $€ 300$ per cow annually (Fluit, 2012).

Antibiotic resistance is a challenging threat to human and animal health (Silva et al., 2020). Indeed, S. aureus is extraordinarily capable of developing resistance to various antimicrobial drugs (Foster 2017). Moreover, the massive use of antibiotics in veterinary medicine is a critical aspect for the dissemination of antibiotic resistant bacteria to humans that poses a significant risk for public health (Salauddin et al., 2020). Penicillin was first discovered in 1929 and it showed antibacterial action against S. aureus (Fleming 1929). By 1940, penicillin was introduced into clinic as an effective antibiotic against infectious diseases including S. aureus and by the massive usage of penicillin in treatment in 1950; penicillin resistant S. aureus stains had emerged that were capable of producing penicillinase, which hydrolyze beta-lactam ring of penicillin. Afterwards in 1959, methicillin antibiotics were administrated for treatment of infections caused by penicillin resistant S. aureus; however, Methicillin resistant S. aureus strains emerged in 1961 (Guo et al., 2020). Methicillin resistance is encoded mecA and mecC genes that encode for penicillin-binding protein $2 \mathrm{a}$ (PBP2a), these genes are carried on a mobile genetic element called Staphylococcal chromosomal cassette mec (SCCmec) (Khairullah et al., 2020).

The emergence of multi-drug resistant S. aureus (MDR) and methicillin resistant $\mathrm{S}$. aureus (MRSA) is a rising public health concern; therefore, this study was designed to monitor the prevalence of Staphylococcus aureus in cow's mastitis milk with determination of the resistance profile of Staphylococcus aureus isolates to different antibiotics to identify the MDR S. aureus and MRSA strain. Polymerase chain Reaction through mecA gene.

\section{MATERIAL AND METHODS}

\subsection{Milk samples:}

Collection of one hundred milk samples $(\mathrm{n}=100)$ from Egyptian cows suffering from mastitis in Kalyuobia Governorate in between April to October 2020.

The samples were collected aseptically from cows with clinical signs of mastitis including inflammation of the udder, milk discoloration and decreased milk production and immediately transported to the laboratory in an ice container (Hogan et al., 1999).

2.2. Isolation of $S$. aureus from mastitis milk using conventional cultural method (Quinn et al., 2002 and Arora 2003):

* Corresponding author: vet.alaanady@gmail.com 
One $\mathrm{ml}$ of milk was inoculated into nutrient broth (Oxoid $\mathrm{CM} 0001$ ), incubated aerobically at $37^{\circ} \mathrm{c}$ for $12 \mathrm{hrs}$. A loopful from the incubated nutrient broth was streaked onto nutrient agar (Oxoid CM0003) and incubated for $24 \mathrm{~h}$ at $37^{\circ} \mathrm{c}$ for 24 hrs. After that, the suspected colony were subculture on Baird Parker agar (Oxoid CM1127) supplemented with Egg Yolk Tellurite Emulsion (Oxoid SR0054), mannitol salt agar (Oxoid CM0085) and 5\% sheep blood agar (CM0055) and incubated at $37^{\circ} \mathrm{c}$ for $24-48 \mathrm{hrs}$. The suspected colonies (black colonies with yellow halo around them on the Baird Parker agar, yellow colonies surrounded by halo zone on mannitol salt agar and white or yellow, smooth round, hemolytic and shiny colonies on blood agar) were picked up and kept in semi-solid agar for biochemical identification.

2.3. Biochemical identification of S. aureus isolates (Quinn et al., 2002 and Arora, 2003):

It was performed by application of Gram staining, catalase, coagulase, oxidase, sugar fermentation, indole, triple sugar iron, Methyl red, Voges-Proskauer and Urease tests.

2.4. Anti- microbial resistance profile of S. aureus isolates: Staphylococcus aureus isolates were submitted to antimicrobial susceptibility testing by using disc diffusion method CLSI (2017) for 9 antibiotics; cefoxitin (F0X,

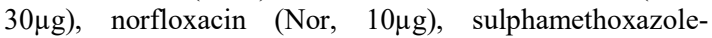

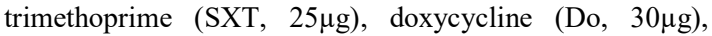
clindamycin (DA, $2 \mu \mathrm{g}$ ), amoxicillin (AX, $25 \mu \mathrm{g}$ ), ofloxacin (Ofx, $5 \mu \mathrm{g})$, gentamicin $(\mathrm{CN}, 2 \mu \mathrm{g})$, oxacillin (Ox, $1 \mu \mathrm{g})$. (Table 1).

Sterile Mueller- Hinton Agar plates (Oxoid CM0337) were swabbed with bacterial suspension equivalent to 0.5 McFarland then placement of the antimicrobial discs onto the agar was done using sterile forceps and to ensure the complete contact with the agar surface, it was press gently and incubated at $35^{\circ} \mathrm{c}$ for $24 \mathrm{hr}$. The diameter of the inhibition zone around the antimicrobial discs were measured and interpreted according to Nccls (2007).

2.4.1 Identification of multi-Drug resistant (MDR) S. aureus isolates:

Staphylococcus aureus were identified as isolates showing resistance to three or more antimicrobial drugs from different categories (Rota., 1996). Staphylococcus aureus were screened by susceptibility testing for cefoxitin $30 \mu \mathrm{g}$ and oxacillin $1 \mu \mathrm{g}$ and isolates showing inhibition zone with diameter $\leq 23 \mathrm{~mm}$ and $10 \mathrm{~mm}$ for cefoxitin $30 \mu \mathrm{g}$ and oxacillin $1 \mu \mathrm{g}$ respectively, were identified as MRSA.

2.5. PCR for identification of mecA gene for resistance of $M R S A$ :

Ten $(\mathrm{n}=10) S$. aureus isolates including 5 phenotypic MRSA (2 fox,3ox) and 5 MDR $S$. aureus selected and submitted to PCR targeting mecA gene of mecithillin resistance $S$. aureus using forward primer $\mathrm{F}$ mecAl 5, GTAGAAATGACTGAACGTCCGATAA3' and reverse primer $\mathrm{R} \quad \operatorname{mecA2} 5$, CCAATTCCACATTGTTTCGGTCTAA with 310 bp amplicon size (McClure et al., 2006).

2.5.1. Extraction of genomic DNA from S. aureus isolates: It was performed using QIAamp DNA mini kit instructions (Qiagen, cat no. 51304) according to manufacturer's instructions.

2.5.2. Amplification and cycling conditions of PCR targeting mecA gene of $S$. aureus isolates:

performed according to McClure et al., (2006) and (Emerald Amp GT PCR master mix 2x premix (Takara code no. RR310A). PCR amplification was carried out on T3 thermal cycler (Biometra) using $25 \mu \mathrm{l}$ reaction volume containing $12.5 \mu 1$ master mix (Takara code no. RR310A), $1 \mu 1$ of each forward and reverse primer, $4.5 \mu 1$ molecular biology grade water and $6 \mu 1$ test DNA at a thermal profile of 1 cycle at
$94 \mathrm{c}$ for $10 \mathrm{~min}: 35 \mathrm{cycles}$ of at $94^{\circ} \mathrm{c}$ for $45 \mathrm{~s}, 50^{\circ} \mathrm{c}$ for $45 \mathrm{~s}$, $72^{\circ} \mathrm{c}$ for $45 \mathrm{~s}$ and $1 \mathrm{cycle}$ of final extension at $72^{\circ} \mathrm{c}$ for 10 min. Then the amplicons were detected by agarose gel electrophoreses on $1.5 \%$ agarose gel stained by ethidium bromide and examined by gel documentation system (biorad) (Sambrook et al., 1989).

\section{RESULTS}

3.1. Isolation of $S$. aureus from cow's mastitis milk:

After screening one hundred of milk samples of Egyptian cows suffered from mastitis that were isolated on mannitol salt agar $30 \mathrm{~S}$. aureus with yellow color surrounded by yellow halo (ferment mannitol) and appear circular, smooth, and opaque with B-hemolysis on blood agar. Growth of those isolates on Baired Parker medium showed black small $1 \mathrm{~mm}$ colonies after 24 hours incubation and large $2.5 \mathrm{~mm}$ after 48 hours incubation surrounded by an opalescent ring and a clear zone. The $S$. aureus isolates showed positive results for gram staining with the characteristic grape like clusters by oil immersion oil).

3.2. Biochemical reactions:

Staphylococcus aureus isolates were positive for catalase, coagulase, V-P test and negative oxidase testes. The results revealed that 30 out of 100 raw milk samples $(30 \%)$ were positive for staphylococcus aureus. Out of those 30 samples, $20(66.6 \%)$ were coagulase positive Staphylococcus aureus (COPS). while $10(33 \%)$ were coagulase negative Staphylococci aureus (CONS).

3.3. In-vitro antimicrobial test (antibiogram activity):

In our study, S. aureus isolates were showed variable resistant against antimicrobial agents. The highest sensitivity towards ofloxacin $(100 \%)$, Do $(100 \%)$ followed by FOX $(90 \%)$, amoxicillin $(85 \%)$, gentamicin $(75 \%)$, Nor (70\%), sxI (65\%), DA (55\%), oxacillin (35\%) were showed among the S. aureus isolates. This study presents S. aureus that the overall high percent of $\mathrm{S}$. aureus isolate resistant to OX $(60 \%)$, DA $(30 \%)$, SXI $(20 \%)$, Nor $(20 \%)$, FOX $(10 \%)$, CN (5\%), DO (0\%), OFX (0) However, low numbers of isolates showed intermediate resistance for DA (15\%), SXI $(15 \%), \mathrm{CN}(20 \%)$.

Most of S. aureus isolates were verified as multi-drug resistant S. aureus (MDR-SA), where 5/20 (25\%) isolates were resistant to three or more antimicrobial agents from different groups of antimicrobials as shown in

(Table 2).

It was found that fluroquinolone members: norfloxacin, tetracycline (DO) and ofloxacin showed the lowest resistance ratio of $5 / 20(25 \%), 0 / 20(0 \%)$, and0/20 $(0 \%)$, respectively, while Oxacillin, clindamycin displayed the highest resistant in ratios of $65 \%, 30 \%$ respectively.

3.4.(MRSA screening test):

The effect of 30- $\mu$ g cefoxitin,1- $\mu \mathrm{g}$ oxacillin discs on $S$. aureus isolate and the MRSA isolates was assessed Staphylococcus aureus strain $(\mathrm{n}=18)$ was found to be sensitive to cefoxitin $(30 \mu \mathrm{g})$ and the zone of inhibition was estimated, while the MRSA isolates (2/20) $10 \%$ were resistant and not affected by cefoxitin. On the other side MRSA isolates 13/20 (65\%) were oxacillin resistant (table $1)$.

3.5. Result of PCR for mecA gene detectionSSS:

The PCR amplification of the 10 phenotypically MRSA isolates ( 2 resistant to fox,3resistant to ox and 5 MDR) was revealed that $6 / 10(60 \%)$ of them were found to carrymec $\mathrm{A}$ gene, which amplified at $310 \mathrm{bp}$. (figure 1). 
Table 1 results of screening test

\begin{tabular}{|c|c|c|}
\hline $\begin{array}{l}\text { Isolate } \\
\end{array}$ & Oxacillin (1 $1 \mu \mathrm{g})$ & Cefoxitin (30ug) \\
\hline 1 & $\mathrm{R}$ & $\mathrm{s}$ \\
\hline 2 & $\mathrm{R}$ & $\mathrm{s}$ \\
\hline 3 & $\mathrm{R}$ & $\mathrm{s}$ \\
\hline 4 & $\mathrm{R}$ & $\mathrm{R}$ \\
\hline 5 & $\mathrm{~s}$ & $\mathrm{~s}$ \\
\hline 6 & $\mathrm{~s}$ & $\mathrm{~s}$ \\
\hline 7 & $\mathrm{~s}$ & $\mathrm{~s}$ \\
\hline 8 & $\mathrm{R}$ & $\mathrm{s}$ \\
\hline 9 & $\mathrm{R}$ & $\mathrm{s}$ \\
\hline 10 & $\mathrm{R}$ & $\mathrm{s}$ \\
\hline 11 & $\mathrm{~s}$ & $\mathrm{R}$ \\
\hline 12 & $\mathrm{~s}$ & s \\
\hline 13 & $\mathrm{R}$ & $\mathrm{s}$ \\
\hline 14 & $\mathrm{R}$ & $\mathrm{s}$ \\
\hline 15 & $\mathrm{R}$ & $\mathrm{s}$ \\
\hline 16 & $\mathrm{~s}$ & $\mathrm{~s}$ \\
\hline 17 & $\mathrm{R}$ & $\mathrm{s}$ \\
\hline 18 & $\mathrm{R}$ & $\mathrm{s}$ \\
\hline 19 & $\mathrm{R}$ & s \\
\hline 20 & $\mathrm{~s}$ & $\mathrm{~s}$ \\
\hline
\end{tabular}

R: Resistant, $\quad$ S:Sensitive

Table 2 Staphylococcus aureus resistance against different Antimicrobial Agents norfloxacin (Nor), sulphamethoxazole-trimethoprime (SXT), doxycycline(D), clindamycin (DA), amoxicillin (AX), ofloxacin (Ofx), gentamicin (CN)

\begin{tabular}{|c|c|c|c|c|c|c|c|}
\hline \multirow{2}{*}{$\begin{array}{l}\text { Antimicrobial } \\
\text { Agent }\end{array}$} & \multirow{2}{*}{$\begin{array}{l}\text { Disk } \\
\text { Conc. }\end{array}$} & \multicolumn{2}{|c|}{ Sensitive } & \multicolumn{2}{|c|}{ 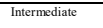 } & \multicolumn{2}{|c|}{$\begin{array}{l}\text { Resistant } \\
\end{array}$} \\
\hline & & $\begin{array}{l}\mathrm{N} \\
0 .\end{array}$ & $\%$ & No. & $\%$ & No. & $\%$ \\
\hline$\overline{O F X}$ & $5 \mu \mathrm{g}$ & 20 & 100 & $\overline{0}$ & 0 & 0 & 0 \\
\hline $\mathrm{AX}$ & $25 \mu \mathrm{g}$ & 16 & 85 & 2 & 10 & 2 & 10 \\
\hline $\mathrm{CN}$ & $10 \mathrm{\mu g}$ & 15 & 75 & 4 & 20 & 1 & 5 \\
\hline DO & $30 \mathrm{\mu g}$ & 20 & 100 & 0 & 0 & 0 & 0 \\
\hline NOR & $10 \mathrm{\mu g}$ & 14 & 70 & 2 & 10 & 4 & 20 \\
\hline SXT & $25 \mathrm{\mu g}$ & 13 & 65 & 3 & 15 & 4 & 20 \\
\hline DA & $2 \mu \mathrm{g}$ & 11 & 55 & 3 & 15 & 6 & 30 \\
\hline ox & $1 \mu \mathrm{g}$ & 8 & 35 & 0 & 0 & 12 & 60 \\
\hline FOX & $30 \mathrm{\mu g}$ & 18 & 90 & 0 & 0 & 2 & 10 \\
\hline
\end{tabular}

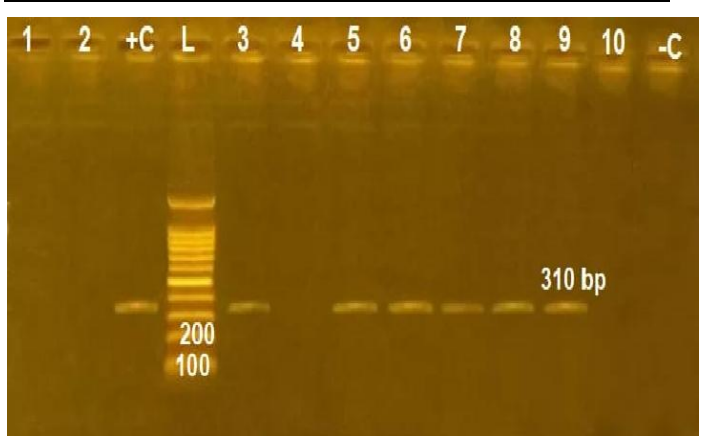

Figure 1 Agarose gel electrophoresis of the amplified mecA gene PCR product (310 bp) for the five methicillin-resistant $S$. aureus (MRSA). Lane L:100-600bp DNA Ladder. C-: Neg. control, C+: Pos. control (S.aureus reference ATCC 25923), Lane 3:5:6:7:8 \&9:Positive strains for mecA gene at $310 \mathrm{bp}$.

\section{DISCUSSION}

Staphylococcus aureus is one of the most widespread pathogens in the globe. S. aureus is able to make infection through which different virulence factor. Firstly, bacteria invade the host then established and escape from destruction by the immune system beyond enzymes, toxin, adhesion molecules (Kuroda et al.2001; Langley et al. 2017).

Around this study, Staphylococcus aureus isolates were Gram positive cocci arranged like grape aerobic growing, coagulase positive. The morphological and biochemical characters of $S$. aureus isolates were similar to Harmon et al., (1991), Howard \& Kloss (1993) and Wladimir et al., (2000). The bacteriological results of 100 samples of cow's mastitis milk cleared that $20 \mathrm{~S}$. aureus isolates $(20 \%)$. The results of $S$. aureus isolation were nearly similar to those recorded by El-kholyetal (1994), Fabre et al. (1997), Baudet \& chieze (1994), Andrade(2001), Janosi \& Baltay (2004)and Saini et al.,(1994) who reported that $S$. aureus isolates were $(22.9 \%),(29 \%),(30 \%),(30.2 \%),(32.5 \%)$ and $(34 \%)$ respectively. But our results were disagreed with those obtained by Gianneechini et al. (2002) who isolated $S$. aureus with higher incidence reached (62.8\%).

The variations between the isolation rate of $S$. aureus were due to geographic distribution, biosecurity practices in the study area as well as difference in immunological status These factors might cause decrease in the isolation rate of $\mathrm{S}$. aureus infection.

The results of antibiogram for the isolated $S$. aureus $(\mathrm{n}=20)$ were revealed that, highest sensitivity towards ofx $(100 \%)$, Do $(100 \%)$ followed by FOX $(90 \%)$, amoxicillin $(85 \%)$, gentamicin $(75 \%)$, Nor $(70 \%)$, sxI $(65 \%)$, DA $(55 \%)$, oxacillin( $35 \%$ ), This study presents high percent of $S$. aureus isolate resistant to OX (60\%), DA (30\%), SXI (20\%) ,Nor(20\%), FOX (10\%), CN(5\%), DO (0\%), OFX(0), Nearly similar to Corti et al. (2003) recorded that $(91 \%)$ of the $S$. aureus strains were sensitive to all antimicrobial, while the isolated strains of $\mathrm{S}$.aureus were resistant to pencillin $\mathrm{G}$ and ampicillin with percentage (9\%) and (7) respectively. Nearly similar to Andrada et al. (2000) and Chowdhury et al. (2002). While Gentilini et al. (2000) recorded resistance to gentamicin (3.4\%). Moreover, the current results proved that MDR are widely spread among $S$. aureus $n$ strains and the misuse of antimicrobials agent $\mathrm{s}$ in the bovine farms in Egypt might be the main cause of multidrug resistance appearance for S. aureus.

Application of MRSA screening test showed that $13 / 20 \mathrm{~S}$. aureus isolates resist to oxacillin and $2 / 20$ resist for cefoxitin. This test revealed that $6 / 20$ of cops isolate were methicillin resistant staphylococcus aureus (MRSA). The current findings were agreed with Tenhagen et al., (2009).

The PCR technique is used for mecA gene detection in 10 MRSA isolates from cows' mastitis milk which were MDR. The PCR results showed 6/10 MDR S. aureus strains positive for mecA gene at $310 \mathrm{bp}$. This result was agreed with (Nunes et al., 2007), Virgin et al.,2009). On the other side, Alian et al. (2012) were disagreed with our results.

\section{CONCLUSION}

This study concluded that staphylococcus aureus represents high prevalence in cow's milk in Kalyuobia governorate. The increase in common antimicrobial agents, resistance used in the treatment against bovine mastitis led to the potential risk of MRSA transmission from animal to human. 


\section{REFERENCES}

1. Abebe, M., Daniel, A., Yimtubezinash, W., Genene, T. 2013. Identification and antimicrobial susceptibility of Staphylococcus aureus isolated from milk samples of dairy cows and nasal swabs of farm workers in selected dairy farms around Addis Ababa, Ethiopia. Afr. J. Microbiol. Res., 7: 3501-3510.

2. Abera, M., Demie, B., Aragaw, K., Regassa, F., Regassa, A. 2013. Isolation and identification of Staphylococcus aureus from bovine mastitic milk and their drug resistance patterns in Adama town, Ethiopia. J. Vet. Med. Ani. Health, 2 :29-34.

3. Alian, F., Rahimi, E., Shakerian, A., Momtaz, H., Riahi, M., Momeni, M. 2012. Antimicrobial resistance of Staphylococcus aureus isolated from bovine, sheep and goat raw milk. Global Veterinaria, 8:111-114.

4. Andrade, M.A. 2001. Subclinical bovine mastitis: Prevalence etiology and sensitivity to antimicrobial drugs test. Ahora Veterinaria, 20(119): 19-26.

5. Arora, D.R. 2003.Text Book of Microbiology .2nd Edition (cultural characteristics of Staphylococcus pp (202-2013).Publishing by Sattish Kumar Jain for CBS publishers.

6. Baudet, H.M., Chieze, C. 1994.Investigation into the nature and frequency of bacterial species isolated from cases of subclinical mastitis at drying off. Bulletin Mensuel de la SociétéVétérinaire Pratique défiance, 78(3):129-136.

7. Boss, R., Cosandey, A., Luini, M., Artursson, K., Bardiau, M., Breitenwieser, F., Hehenberger, E., Lam, T. et al. 2016. Bovine Staphylococcus aureus: subtyping, evolution, and zoonotic transfer. J Dairy Sci 99, 515- 528 .

8. Chowdhury, M., Saha, G.R., Chowdhury, J., Das, S.K. 2002. Subclinical mastitis in crossbred cows. J. of Interacademicia. 6 (Special): 712-715.

9. Coelho, S.M.O., Reinoso, E., Pereira, I.A., Soares, L.C., Demo, M., Bogni, C., Souza, M.M.S. 2009. Virulence factors and antimicrobial resistance of Staphylococcus aureus isolated from bovine mastitis in Rio de Janeiro. Pesq. Vet. Bras; 29: 369-374.

10. Corti, S., Sicher, D., Regli, W., Stephan, R. 2003. Current data on antibiotic resistance of the most important bovine mastitis pathogens in Switzerland. Schweiz Arch Tierheilkd. 145(12): 571-575.

11. El-Kholy, A.M., Hossein, H.I., Thabet, A.R. 1994. Chemical and cytobacteriological studies for the detection of subclinical mastitis. Assiut Vet. Med. J., 30(60): 154164.

12. Fabre, J.M., Morvan, H., Lebreux, B., Houffschmitt, P., Berthelot, X. 1997. Prevention of bacteria causing mastitis in France.Part2: Subclinical mastitis. Bulletin des G.T.V. 5: 9-15.

13. Fleming A. 1929. On the antibacterial action of cultures of a Penicillium with special reference to their use in the isolation of B. influenza. Br J Exp Pathol.; 10:22636.

14. Fluit, A. C. 2012. Livestock-associated Staphylococcus aureus. Clinical Microbiology and Infection, 18(8), 735-744. doi:10.1111/j.1469-0691.2012.03846. x.

15. Foster, T. J. 2017. Antibiotic resistance in Staphylococcus aureus. Current status and future prospects. FEMS Microbiology Reviews, 41(3), 430449. doi:10.1093/femsre/fux007.

16. Gentilini E, Denamiel G, Llorente P, Godaly S, Rebueto M, DeGregorio O 2000. Antimicrobial susceptibility testing of Staphylococcus aureus isolated from bovine mastitis in Argentina. J. Dairy Sci., 83: 1224-1227.

17. Gianneechini, R., Concha, C., Rivero, R., Delucci, I., Moreno, L. J. 2002. Occurrence of clinical and subclinical mastitis in dairy herds in the West Littoral Region in Uruguay. Acta Vet Scand., 43(4): 221-230.

18. Guo, Y., Song, G., Sun, M., Wang, J., \& Wang, Y 2020. Prevalence and Therapies of AntibioticResistance in Staphylococcus aureus. Frontiers in Cellular and Infection Microbiology, 10 doi:10.3389/fcimb.2020.00107.

19. Harmon, R.J., Langlois, B.E., Dellinger, J.D.1991.A simple medium for the verification of identity of $\mathrm{S}$. aureus of bovine origin. J. Dairy Sci., 74(1): 202.

20. Heleili, N., Ayachi, A., Melizi, M. and Mamache, B. 2012. Prevalence of subclinical bovine mastitis and the in vitro sensitivity of bacterial isolates in Batna governorate, East of Algeria. J Anim Sci Adv 2, 576- 582 .

21. Hogan J., Gonzalez R., Harmon R., Nickerson S., Oliver S., Pankey J., et al. 1999. Laboratory Handbook on Bovine Mastitis. Verona, WI: National Mastitis Council Madison].

22. Howard, B.J., Kloss, W.E. 1993. Staphylococci. Chapter 12. In: Clinical and pathogenic Microbiology, 2nd edition. pp. 243-256.

23. Janosi, S., Baltay, Z. 2004. Correlation among the somatic cell count of individual bulk milk result of the California Mastitis Test and bacteriological status of the udder in dairy cows. Acta. Vet. Hung., 52(2): 173183

24. Khairullah, A. R., Sudjarwo, S. A., Effendi, M. H., Harijani, N., Tyasningsih, W., Rahmahani, J., Permatasari, D. A., Ramandinianto, S. C., Widodo, A. and Riwu, K. H. P. 2020. A Review of MethicillinResistant Staphylococcus aureus (MRSA) on Milk and Milk Products:Public Health Importance. Sys Rev Pharm, 11(8):59-69.

25. Kuroda, M., Ohta, T., Uchiyama, I., Baba, T., Yuzawa, H., Kobayashi, I. and Cui, L. 2001. Whole genome sequencing of meticillin-resistant Staphylococcus aureus. Lancet 357, 1225- 1240.

26. Langley, R.J., Ting, Y.T., Clow, F., Young, P.G., Radcliff, F.J., Choi, J.M., Sequeira, R.P., Holtfreter, S. et al. 2017. Staphylococcal enterotoxin-like $\mathrm{X}$ (SEIX) is a unique superantigen with functional features of two major families of staphylococcal virulence factors. PLoS Pathog 13, 1-29.

27. Mamache,B., Rebehi, S. and Meziane, T. 2014. Bacteriological study of subclinical mastitis inBatna and Setif Governorates Algeria. J Vet Adv Bacteriol 4, 364- 373.

28. McClure, J. A., Conly, J. M., Lau, V., Elsayed, S., Louie, T. Hutchins, W., \& Zhang, K. (2006). Novel multiplex PCR assay for detection of the staphylococcal virulence marker Panton-Valentine leukocidin genes and simultaneous discrimination of methicillin-susceptible from-resistant staphylococci. Journal of clinical microbiology, 44(3), 1141-1144.

29. Mirzaei, H., Farhoudi, H., Tavassoli, H., Farajli, M., Monadi, A. 2012. Presence and antimicrobial susceptibility of methicillin resistant Staphylococcus aureus in raw and pasteurized milk and ice cream in Tabriz by culture and PCR techniques. Afr. J. Microbiol. Res., 6: 6224-6229. 
30. NCCLS 'National Committee for Clinical Laboratory Standards'1999. Performance standards for antimicrobial disk and dilution susceptibility tests for bacteria isolated from animals. Approved standard M13-A. Wayne: NCCL.

31. Nemeghaire, S., Argudin, M. A., Haesebrouck, F., and Butaye, P. (2014). Epidemiology and molecular characterization of methicillin-resistant Staphylococcus aureus nasal carriage isolates from bovines. BMC Vet. Res. 10:153. doi: 10.1186/17466148-10-153.

32. Nunes, S.F., Bexiga, R., Cavaco, L.M., Vilela, C.L. 2007. Technical note: Antimicrobial susceptibility of Portuguese isolates of Staphylococcus aureus and Staphylococcus epidermidis in subclinical bovine mastitis. J. Dairy Sci., 90:3242-3246.

33. Pal, M., Kerorsa, G. P., Marami, L. M., Kandi. V. 2020 Epidemiology, Pathogenicity, Animal Infections, Antibiotic Resistance, Public Health Significance, and Economic Impact of Staphylococcus aureus: A Comprehensive Review. American Journal of Public Health Research, 2020, Vol. 8, No. 1, 14-21 DOI: 10.12691/ajphr-8-1-3.

34. Quinn, P.J., Carter, M.E., Markey, B.K., Donnoly ,W.J., and Leonard,F.C. 2002. Veterinary microbiology and microbial disease.166-11170sney Mead,Oxford firstLTd, Registered at the United kingdom.

35. Richard, G., Herrman, W., Daniel, I., Doris, E., Dave, f ., 2010 Management practices associated with bulk milk prevalence of Staphylococcos aureus in Canadian dairy farms.

36. Rota C, Yanguela J, Blanco D, Carraminana JJ, Arino A, Herrera A. 1996. High prevalence of multiple resistance to antibiotics in 144 Listeria isolates from Spanish dairy and meat products. J Food Prot.;59: 938943.

37. Saini, S.S., Sharma, J.K., Kwarta, M.S. 1994. Prevalence and etiology of subclinical mastitis among crossbred cows and buffaloes in Punjab. Ind. J. Dairy Sci., 47(2): 103-106.

38. Salauddin, M., Akter, M. R., Hossain, M. K., Nazir, K. H. M. N. H., Noreddin, A., \& El Zowalaty, M. E. 2020. Molecular Detection of Multidrug Resistant Staphylococcus Aureus Isolated from Bovine Mastitis Milk in Bangladesh. Veterinary Sciences, 7(2), 36. doi:10.3390/vetsci7020036.

39. Sambrook, J.; Fritscgh, E.F.; and Mentiates 1989. Molecular coloning. A laboratory manual. Vol. Cold spring Harbor Laboratotry press, New York.

40. Silva, I., Tacão, M., \& Henriques, I .2020. Selection of antibiotic resistance by metals in a riverine bacterial community. Chemosphere, 127936.2020.127936.

41. Sudhan, N.A., Singh, R., Singh, M., Soodan, J.S. 2005. Studies on prevalence, etiology and diagnosis of subclinical mastitis among crossbred cows. Indian J. Anim. Res., 39: 127-130.

42. Tenhagan, B.A., Hansen, I., Reinecke, A., Heuwieser, W. 2009. Prevalence of pathogens in milk samples of dairy cows with clinical mastitis and in heifers at first parturition. J. Dairy Res., 76(2): 179-187.

43. Virgin, J.E., Van Slyke, T.M., Lombard, J.E., Zadoks, R.N. 2009. Short communication: methicillin-resistant Staphylococcus aureus detection in US bulk tank milk. J. Dairy Sci., 92: 4988-4991.

44. Wladimir, P., Da Silva, Maria Teresa, D., Mariza, L., Bernadette, D.G.M. Franco. 2000. Biochemical characteristics of typical and atypical Staphylococcus aureus in mastitic milk and environmental samples of
Brazilian dairy farms. Brazilian Journal of Microbiology 31: 103-106. 